\title{
Scrutiny of Microorganisms in Fermented Milk Beverage and Water from Dairy under State Inspection
}

\author{
Kristy Ellen Oliveira Santos, Ludmilla Santana Soares e Barros \\ Federal University of Recôncavo of Bahia, Cruz das Almas, Brazil \\ Email: barros@ufrb.edu.br
}

How to cite this paper: Santos, K.E.O. and Barros, L.S.S. (2021) Scrutiny of Microorganisms in Fermented Milk Beverage and Water from Dairy under State Inspection. Food and Nutrition Sciences, 12, 1008-1019. https://doi.org/10.4236/fns.2021.1211074

Received: September 17, 2021

Accepted: November 8, 2021

Published: November 11, 2021

Copyright $\odot 2021$ by author(s) and Scientific Research Publishing Inc. This work is licensed under the Creative Commons Attribution International License (CC BY 4.0).

http://creativecommons.org/licenses/by/4.0/ (c) (i) Open Access

\begin{abstract}
The aim of the study was to examine microorganisms in samples of fermented milk beverage and water from dairy under state inspection. In a dairy located in the Recôncavo of Bahia, fifteen samples of fermented milk beverage were collected, corresponding to three different batches, and six water samples, two from each point of use in the industry: Point $1-$ Sanitary barrier; Point 2-Internal faucet for cleaning surfaces and utensils; Point 3-Drinking fountain for employees. All samples were submitted to microbiological research of total coliforms, Escherichia coli and Aeromonas spp. In the water samples, there was also quantification of heterotrophic bacteria and analysis of free residual chlorine. The fermented milk beverage samples did not show growth of total coliforms, E. coli and Aeromonas spp. With regard to water, no sample showed measurable levels of free residual chlorine, while in the microbiological analysis the count of heterotrophic bacteria in the drinking water exceeded the limit established by legislation $\left(5.6 \times 10^{2} \mathrm{CFU} \cdot \mathrm{mL}^{-1}\right)$. In addition, the water from the sanitary barrier revealed total coliforms above the allowed value $\left(1.3 \times 10^{1} \mathrm{CFU} \cdot 100 \mathrm{~mL}^{-1}\right)$ and showed contamination by Aeromonas spp. $\left(7.0 \times 10^{1} \mathrm{CFU} \cdot \mathrm{mL}^{-1}\right)$. Thus, it can be inferred that, although the fermented milk beverage did not present the investigated microorganisms, the water used by the industry showed microbial contamination, and due to its participation in the entire production process, water quality control is extremely important to prevent contamination of the food handler and the final product, preventing the spread of diseases and harm to public health.
\end{abstract}

\section{Keywords}

Milk Derivatives, Water Quality, Good Practices, Public Health 


\section{Introduction}

According to the Technical Regulation on the Identity and Quality of Dairy Beverages, approved by Normative Instruction No. 16, of August 23, 2005 of the Ministry of Agriculture, Livestock and Supply, which defines each type of dairy beverage and the quality requirements, the fermented dairy beverage is the product obtained through the association between milk and whey, with or without the addition of food substances, submitted to the lactic fermentation process and must have at least $51 \%$ milk-based mass/mass of the total ingredients used [1]. In addition to being an economically more viable dairy product for the population, it also has a reduced cost in its production and promotes the reuse of whey, avoiding its disposal in inappropriate places, thus reducing environmental pollution [2].

Milk and its by-products have high water activity and several nutrients, which are some of the characteristics that can favor microbial development; it is emphasized that foods with high water activity (Aw greater than 0.90) increase the perishability of the product and provide a substrate for microbial multiplication, reducing shelf life and generating significant economic losses [3]. Thus, the sanitary control of these foods is essential to maintain the quality of the raw material until the final product, and can be carried out through the establishment of standards and methods used to verify the application of Good Practices during the manufacture, handling and distribution of these products [4] [5].

When the hygienic-sanitary procedures are not performed properly in the manufacturing process, it increases the risk of food contamination by physical, chemical and microbiological parameters, which may cause so-called foodborne diseases (FD). Water and dairy products are among the main foods involved in cases of FD outbreaks that occurred from 2007 to 2019 in Brazil, according to data published by the Ministry of Health. Microbiological contamination is the main cause of FD and among the factors predisposing factors for the spread of microorganisms in food are improper raw materials, inadequate handling and incorrect conservation [6] [7] [8] [9].

It is noticed that the production of food safely and in compliance with hygiene standards depends on the control of several factors. Thus, it is important to emphasize the participation of water in the entire production process, acting as a resource of great importance for the dairy industry in reason of the direct influence it exerts on product quality due to the various functions it performs in different stages during the dairy processing, such as cleaning environments, equipment and utensils, acting on the sanitary barrier for entry into the production sector, hand hygiene of food handlers, ingestion by industry employees, in thermal processes in machinery, boilers and incorporation in some products [10].

To meet the daily demands of human consumption and food production, water must meet two main requirements, be available in sufficient quantity for its intended purpose and present ideal quality as recommended by Consolidation 
Ordinance No. 5 of September 282017 of the Ministry of Health, which, among other determinations, provides for the standard of potability, the physicochemical and microbiological characteristics required and the procedures for maintaining water quality [11].

The industry can obtain water through the public supply or its own supply, but regardless of the source, it must be subjected to adequate treatment and meet the potability criteria established before being used, in order to avoid the dissemination of several microorganisms as heterotrophic bacteria, total coliforms, Escherichia coli and Aeromonas spp. [11] [12]. Therefore, water quality should not be neglected, as this element is present in the most diverse phases of food production in contact with the raw material, with the equipment and the food handlers, which can cause cross-contamination of the final product and possible cases of FD [6].

According to Franco and Landgraf [3], microbiological analyzes aimed at researching the quality of water and food products are very relevant. For Reis, Penna and Hoffmann [13], research of microbiological contaminants in food can provide an overview of the need to apply both preventive and corrective measures through quality control, following the recommended maintenance of Good Practices in manufacturing. From this perspective, there are studies related to the research of microorganisms in water and in a fermented milk beverage separately, but there is a shortage of studies correlating the possibility of microbial development in both and the potential risks to the consumer, based on this, the aim of this work to investigate microorganisms in fermented milk beverages and water from dairy products under state inspection.

\section{Methodology}

\subsection{Description of the Study and Place of Action}

It was carried out in a dairy unit located in the Recôncavo da Bahia, from October to December 2019. The practical resource was the collection and analysis of samples of fermented milk beverage and dairy production establishment water.

The industry was part of the state inspection system, received milk from regional producers, pasteurized this raw material and then produced dairy products such as fermented milk drinks, yogurt and butter, generating 35 types of products that were sold in establishments in the Recôncavo da Bahia.

\subsection{Collection and Analysis Procedures}

Due to the great diversity of dairy products produced and seeking to maintain the representativeness of the batch, it was decided to carry out the collection and microbiological analysis of fermented milk beverage samples with certification of registration in the state inspection system, being taken directly from the refrigerated chambers in their packaging commercialization and in accordance with the sampling plan determined by Normative Instruction No. 16, of August 23, 2005, of the Ministry of Agriculture, Livestock and Supply, where the sampling 
unit was five products of the same batch, with the same composition, date of validity and manufacturing [1].

In the establishment producing dairy products, the water used came from the public supply, two samples of $100 \mathrm{~mL}$ of water were collected at each established point, one sample for free residual chlorine analysis and one sample for microbiological analysis. Three distinct points were selected: Point 1-Sanitary barrier; Point 2-Internal faucet for cleaning surfaces and utensils; Point 3-Drinking fountain for employees; Totaling six water samples. To collect water from the faucets, it was cleaned with $70 \%$ alcohol and draining the water for 3 minutes. During the collection of water samples at the defined points, Nasco brand sterile polyethylene bags, model Whirl-Pak ${ }^{\circledR}$ Thio-Bag $^{\circledR}$, containing a $10 \mathrm{mg}$ sodium thiosulfate tablet were used in order to inactivate the residual chlorine in the sample for microbiological analysis, and the collection of water for analysis of free residual chlorine was carried out using glass flasks [14].

Soon after acquisition, all samples were identified, packaged and transported in isothermal boxes with reusable ice to the Analytical Research of Food and Water Laboratory (N6) of the Federal University of Recôncavo da Bahia (UFRB) located in Cruz das Almas-BA, where the analyzes were carried out.

Microbiological analyzes of fermented milk beverage and collected water were performed by incubating plates with the samples in a bacteriological incubator at $35^{\circ} \mathrm{C} \pm 2^{\circ} \mathrm{C}$ for a period of 24 hours using the culture medium Agar Chromocult $^{\circledR}$ Coliforms (Merck) for determination of total coliforms and Escherichia coli, and Aeromonas Isolation Agar (Sigma-Aldrich) with addition of selective Aeromonas supplement containing ampicillin for quantification of Aeromonas spp. And to determine the development of heterotrophic bacteria in the water samples, Standard Agar for Counting (Kasvi) was used, under incubation in a bacteriological incubator at $35^{\circ} \mathrm{C} \pm 2{ }^{\circ} \mathrm{C}$ for 48 hours [15].

To detect free residual chlorine, a DPD reagent tablet (dialkyl-1,4-phenylenediamino) was incorporated into a water sample and then read using a digital chlorimeter device [14].

\subsection{Evaluation of Achieved Results}

The results found from the microbiological analyzes of fermented milk beverage and water were expressed in Colony Forming Unit per milliliter $\left(\mathrm{CFU} \cdot \mathrm{mL}^{-1}\right)$, except for the count of total coliforms in water samples that were described as UFC $100 \mathrm{~mL}^{-1}$. To analyze the microbiological results presented by the fermented milk beverage, the standard established in Normative Instruction No. 16, of August 23, 2005, of the Ministry of Agriculture, Livestock and Supply [1] was used. The microbiological and free residual chlorine results from the water were compared with the parameters defined in Consolidation Ordinance No. 5 of September 28, 2017, of the Ministry of Health [11].

\section{Results and Discussion}

The microbiological analyzes performed on samples of fermented milk beverag- 
es did not show the presence of total coliforms and Escherichia coli, therefore, they obeyed the microbiological acceptance criteria established by Normative Instruction No. 16/2005 of the Ministry of Agriculture, Livestock and Supply, related to the product obtained directly from the producing establishment, soon after its manufacture [1]. The microorganism Aeromonas spp. it was also not found in the analysis.

A study by Roma and collaborators [16] also analyzed the deteriorating microbiota of fermented dairy derivatives such as yogurt, fermented milk and dairy beverage, aiming to detect the possibility of contamination during the production process, highlighting the populations of coliforms, proteolytic and lipolytic psychotrophics, within the expiration commercial date.

According to the authors, there was no detection of bacteria from the coliform group and the products did not suffer deterioration during the analyzes carried out during the validity period, being adequate in terms of the hygienic-sanitary quality required by legislation, showing that the hygienic process in the manufacture of the products analyzed and storage at appropriate temperatures allow the product to be preserved and prevent the multiplication of deteriorating microorganisms [16].

It is known that most animal products are favorable to microbial proliferation, however, fermented milk beverages, for presenting a certain level of acidity, are not conducive to the development of total and thermotolerant coliforms. Despite this, studies demonstrate the presence of the coliform group in these fermented foods, considered an indicator of unsatisfactory hygienic and sanitary conditions in the production process [17] [18].

Reis, Penna and Hoffmann [13] investigated the contaminating microbiota in fermented milk beverages produced by small and medium-sized companies, by counting fungi, determining total and thermotolerant coliforms, researching Escherichia coli and Salmonella spp. and evaluation of $\mathrm{pH}$ values. Despite the absence of Salmonella spp., the authors found a high frequency of filamentous fungi and yeast, in addition to the detection of $E$. coli in five samples, corresponding to $16.67 \%$ of the total, being classified as products in unsatisfactory sanitary conditions. Demonstrating that fermented milk beverages are susceptible to microbial contamination, and the application of quality programs by food producers, such as Good Practices, Hazard Analysis and Critical Control Points (HACCP), can prevent contamination risks and offer safe products for the consumer.

Regarding the collected water samples, specifically the analysis of free residual chlorine, no levels of this product were detected. According to Consolidation Ordinance of the Ministry of Health No. 5, of September 28, 2017, art. 34, throughout the water distribution system both in the network and in the tanks, it is mandatory to maintain the minimum value of $0.2 \mathrm{mg} \cdot \mathrm{L}^{-1}$ of free residual chlorine and art. 39, paragraph 2, recommends that the residual free chlorine be a maximum of $2.0 \mathrm{mg} \cdot \mathrm{L}^{-1}$ at any point in the supply system. Based on this, it can be inferred that the analyzed water samples are outside the established standard 
of free residual chlorine, not being suitable for this parameter for use and consumption, as the absence of free residual chlorine can favor the maintenance of microorganisms and product contamination during processing [11].

According to Lopes Júnior and Miguel [19], water acts as an important element at various stages in dairy products and is directly related to the hygiene of handlers, the environment, equipment and utensils, in addition to being used for ingestion by industry employees, and may then be a vehicle of contamination for the manufactured products and transmit water and food diseases if it is not potable. Therefore, it is extremely important to properly treat water, which can occur through chlorination at ideal concentrations.

The result obtained is concerned, as according to a study by Kamiyama [5], who obtained results for total chlorine and free chlorine at low concentrations in water samples collected in twenty dairy agro-industries in Rio de Janeiro, chlorine values below the required can be caused by lack of water treatment or failures in the control of chlorine content, which may interfere with the microbiological quality of the water supply. Even using water from the public supply network, which has been subjected to the correct treatment, there can be a natural loss of residual chlorine contents due to decomposition that occurs along the water's path to the most distant points of use. Thus, quality control must be established through adequate water treatment, regular analyzes and periodic cleaning of tanks.

Silva and collaborators [20] corroborate this, stating the importance of chlorination and microbiological evaluation of water periodically, as in Santa Catarina the authors implemented an automatic chlorinator at the entrance of the water tank of twenty dairy farms and after a period of two weeks the equipment was removed, and water and milk samples were collected, before and after the chlorine treatment. As for the results, they observed that the efficient chlorination process promoted an increase in the microbiological quality of the water with a decrease in total coliforms and pathogenic microorganisms, confirming the need for correct water treatment and the benefit of applying Good Practices.

Regarding the microbiological analyzes performed in this study, there was no detection of Escherichia coli in the water samples, however, the water from the sanitary barrier, which represents $33 \%$ of the samples, had a count of $1.3 \times 10^{1}$ $\mathrm{CFU} \cdot 100 \mathrm{~mL}^{-1}$ of coliforms total and $7.0 \times 10 \mathrm{CFU} \cdot \mathrm{mL}^{-1}$ of Aeromonas spp. All water samples analyzed showed heterotrophic microorganisms, with water from the sanitary barrier $2.5 \times 10^{2} \mathrm{CFU} \cdot \mathrm{mL}^{-1}$, water from the production sector $3.0 \times$ $10^{2} \mathrm{CFU} \cdot \mathrm{mL}^{-1}$ and water from the drinking fountain with $5.6 \times 10^{2} \mathrm{CFU} \cdot \mathrm{mL}^{-1}$.

Ordinance No. 5/2017 of the MH determines that among the criteria for potability of water intended for human consumption and use in food preparation, there must be the absence of total and thermotolerant coliforms in $100 \mathrm{~mL}$ of water. Thus, the presence of total coliforms in the sanitary barrier water sample demonstrates that it is above the permitted standard [11].

Chaves and collaborators [21] also evaluated the sanitary quality of water used in dairy products in Rio Pomba in Minas Gerais, related to the presence of total 
and thermotolerant coliforms, and detected the presence of these microorganisms above ideal in most water samples collected in agroindustries of milk, characterizing itself as a health risk factor.

Ordinance No. 5/2017 determines that in $20 \%$ of the system's monthly water samples the standard count must be performed and that it cannot exceed 500 $\mathrm{CFU} \cdot \mathrm{mL}^{-1}$. There was growth of heterotrophic bacteria in all water samples analyzed, but the sample from the drinking fountain exceeded this defined limit, showing a growth of $5.6 \times 10^{2} \mathrm{CFU} \cdot \mathrm{mL}^{-1}$, in disagreement with what is established by legislation. The presence of these microorganisms provides extra information about possible failures in the sanitation of the distribution system [11].

For Aeromonas spp. there is no mention of values allowed in the legislation, but because it is characterized as a potentially pathogenic microorganism associated with various infections in animals and humans, it is important that it is not present in the water used in food production [12]. Despite this, there was a development of $7.0 \times 10 \mathrm{CFU} \cdot \mathrm{mL}^{-1}$ of Aeromonas spp. in the sanitary barrier sample, which is used for employee hygiene before entering the dairy processing environment.

Cereser and collaborators [22] correlated the results obtained from Aeromonas spp. in water with those found in raw milk from a property in the northwest region of Rio Grande do Sul that supplied refrigerated fresh milk to industries, demonstrating the possibility of cross-contamination of water with food. Mainly spread by water, Aeromonas genus bacteria are relevant opportunistic pathogens, having worldwide importance for causing diseases through direct ingestion or through consumption of food contaminated by previous contact with water [12] [23] [24].

Thus, it can see the influence of the water used in production, as well as the importance of quality of the raw material, Good Practices throughout the manufacture of dairy products and constant verification of the maintenance of adequate physicochemical and microbiological parameters of the water and the food produced.

\section{Conclusions}

The results obtained during the experiment were detailed in the form of reports and delivered to the industry participating in this study in order to contribute to decision making to improve the production process.

Among the evaluated samples of fermented milk beverage, all were in satisfactory sanitary conditions according to the microorganisms studied and in comparison with the current standard for this product. However, despite the fact that unwanted microorganisms were not detected in the fermented milk beverage in this study, the need for constant monitoring through tests that reaffirm the quality, preventing and/or reducing failures that may occur in the process is not ruled out. 
As for the analyzed water samples, there was no detection of free residual chlorine contents and these presented values above the microbiological standard recommended by the legislation in force for the research of total coliforms and heterotrophic bacteria, in addition to the presence of Aeromonas spp., which although not having a limit defined by legislation can cause poisoning and public health problems. Revealing then as a worrying situation, since water is a fundamental element in the dairy industry, which circulates throughout the production process, coming into contact with food handlers, in addition to participating in the cleaning of equipment and utensils, being therefore, a vehicle of contamination to food if it falls short of the desired standards, which can promote foodborne diseases.

Therefore, it is recommended to periodically review the ideal parameters to maintain the potability of water and product quality, as well as cleaning measures for water tanks, maintaining adequate values of free residual chlorine at points of use and applying Good Practices during all food production in order to mitigate risks to public health.

\section{Acknowledgements}

The authors thank the Coordination of Support for Higher Education Personnel for supporting the study.

\section{Conflicts of Interest}

The authors declare no conflicts of interest regarding the publication of this paper.

\section{References}

[1] BRASIL (2005) Ministério da Agricultura Pecuária e Abastecimento. Instrução Normativa $n^{\circ}$ 5, de 23 de agosto de 2005. Aprova o Regulamento Técnico de Identidade e Qualidade de Bebida Láctea. Diário Oficial da União. Brasília-DF.

[2] Thamer, K.G. and Penna, A.L.B. (2006) Caracterização de bebidas lácteas funcionais fermentadas por probióticos e acrescidas de prebiótico. Ciência e Tecnologia de Alimentos, 26, 589-595. https://doi.org/10.1590/S0101-20612006000300017

[3] Franco, B.D.G.M. and Landgraf, M. (2008) Microbiologia dos alimentos. 2 ed, Editora Atheneu, São Paulo.

[4] Rezer, A.P.S. (2010) Avaliação da Qualidade Microbiológica e Físico-Química do leite UHT integral comercializado no Rio Grande do Sul. Dissertação, Universidade Federal de Santa Maria, Santa Maria.

[5] Kamiyama, C.M. (2012) Qualidade da água em laticínios-A realidade da agroindústria participante do programa PROSPERAR/AGROINDÚSTRIA. Dissertação, Universidade Federal de Juiz de Fora, Minas Gerais.

[6] BRASIL (2010) Ministério da Saúde. Secretaria de Vigilância em Saúde. Departamento de Vigilância Epidemiológica. Manual Integrado de Vigilância, Prevenção e Controle de Doenças Transmitidas por Alimentos. Editora do Ministério da Saúde, Brasília, 35-39.

http://bvsms.saude.gov.br/bvs/publicacoes/manual integrado vigilancia doencas a limentos.pdf 
[7] BRASIL (2020) Ministério da Saúde. Secretaria de Vigilância em Saúde. Distribuição temporal dos surtos notificados de doenças transmitidas por alimentosBrasil, 2007-2015. Boletim Epidemiológico, Brasília, 51, 18.

https://www.gov.br/saude/pt-br/centrais-de-conteudo/boletim-epidemiologico-svs32-pdf/view

[8] BRASIL (2020) Ministério da Saúde, Secretaria de Vigilância em Saúde. Doenças transmitidas por alimentos: Causas, sintomas, tratamento e prevenção.

http://portalms.saude.gov.br/saude-de-a-z/doencas-transmitidas-por-alimentos

[9] BRASIL (2020) Ministério da Saúde. Secretaria de Vigilância em Saúde. Informe sobre surtos notificados de doenças transmitidas por água e alimentos-Brasil, 20162019. Boletim Epidemiológico, Brasília, 51, 27-31.

https://www.gov.br/saude/pt-br/centrais-de-conteudo/boletim-epidemiologico-svs32-pdf/view

[10] Cunha, H.V.F. (2016) Qual a importância da água na indústria de alimentos? Food Safety Brazil-Segurança de Alimentos.

https:/foodsafetybrazil.org/importancia-da-agua-na-industria-de-alimentos/

[11] BRASIL (2017) Ministério da Saúde. Portaria de Consolidação $n^{\circ} 5$, de 28 de setembro de 2017. Consolidação das normas sobre as ações e os serviços de saúde do Sistema Único de Saúde. Diário Oficial da União. Brasília-DF.

[12] Tavares, A.B., Cereser, N.D. and Timm, C.D. (2015) Ocorrência de Aeromonas spp. em alimentos de origem animal e sua importância em saúde pública. Arquivos do Instituto Biológico, 82, 1-8. https://doi.org/10.1590/1808-1657000662013

[13] Reis, J.A., Penna, A.L.B. and Hoffmann, F.L. (2013) Microbiota contaminante em bebidas lácteas fermentadas comerciais. Revista do Instituto Adolfo Lutz, 72, 93-98. http://hdl.handle.net/11449/122276

[14] BRASIL (2013) Ministério da Saúde. Fundação Nacional de Saúde. Manual prático de análise de água. 4 ed. Editora Funasa, Brasília.

http://www.funasa.gov.br/site/wp-content/files mf/manual pratico de analise de agua 2.pdf

[15] Silva, N., Junqueira, V.C.A., Silveira, N.F.A., Taniwaki, M.H., Gomes, R.A.R. and Okazaki, M.M. (2017) Manual de métodos de análise microbiológica de alimentos e água. 5 ed. Editora Blucher, São Paulo.

[16] Roma, L.H.A., Lima, W.M.E., Peres, M.P.S. and Souza, S.M.O. (2020) Análise de microrganismos deteriorantes em derivados lácteos fermentados durante o prazo comercial. Pubvet, 14, 157-161. https://doi.org/10.31533/pubvet.v14n11a689.1-5

[17] Lima, R.M.T., Ferraz, L.P.S., Lima, R.C.T., Araújo, G.T, Paiva, J.E. and Shinohara, N.K.S. (2009) Análise microbiológica e físico-química de bebidas lácteas comercializadas no Recife-PE. IX Jornada de Ensino, Pesquisa e Extensão, IV Semana Nacional de Ciência e Tecnologia, Pernambuco, 19-23 October 2009, 1-3.

[18] Reis, J.A., Gonçalves, T.M.V. and Hoffmann, F.L. (2010) Qualidade microbiológica de bebidas lácteas fermentadas, com adição de polpas de frutas, comercializadas na região de São José do Rio Preto. Revista Higiene Alimentar, 24, 157-161.

[19] Lopes Júnior, H.M. and Miguel, V. (2013) Água potável: Monitoramento, controle de processo e ações corretivas. Nota técnica. Revista Técnica do Farmacêutico, São Paulo.

[20] Silva, C.G., Alessio, D.R.M., Knob, D.A., D’Ovidio, L. and Thaler Neto, A. (2018) Influência da sanificação da água e das práticas de ordenha na qualidade do leite. Arquivo Brasileiro de Medicina Veterinária e Zootecnia, 70, 615-622.

https://doi.org/10.1590/1678-4162-9466 
[21] Chaves, K.F., Silva, N.B.N., Vieira, T.B., Mendes, A.C.G., Gravina, C.S., Martins, A.D.O. and Martins, M.L. (2010) Avaliação Microbiológica da Água Empregada em Laticínios da Região de Rio Pomba-MG. UNOPAR Científica Ciênias Biológicas e da Saúde, 12, 5-8.

[22] Cereser, N.D., Rossi Júnior, O.D., Noskoski, L., Camera, L. and Bohrz, D.A.S. (2012) Associação entre o isolamento de Aeromonas spp. em água e leite cru. XVII Seminário Interinstitucional de Ensino, Pesquisa e Extensão-UNICRUZ, Cruz Alta, 11-12 September 2012, 100-104.

[23] Silva, A.S. and Barros, L.S.S. (2020) Food Safety and Fish Farming: Serious Issues for Brazil. Food and Nutrition Sciences (Online), 11, 123-152.

https://www.scirp.org/journal/paperinformation.aspx?paperid=98545

[24] Silva, A.S., Barros, L.S.S., Lima, D.V. and Simões, D.V. (2019) The Occurrence of Bacteria of the Genus Aeromonas spp. in Oreochromis niloticus (Tilapia) and in the Water of Amateur Sport Fish Ponds and Sensitiveness to Antimicrobials. Food and Nutrition Sciences, 10, 81-97.

https://www.scirp.org/journal/paperinformation.aspx?paperid=89948 


\section{Final Considerations}

Milk and its by-products are of great importance in the national economic sector, but due to the intrinsic characteristics of the raw material, associated with the deficiency in Good Practices during manufacturing and the lack of quality of the water used, the production of dairy products can pose a risk to public health for favoring microbial growth, which can cause foodborne diseases, in addition to economic losses to industries due to the accelerated deterioration of food and equipment due to the formation of biofilms through contaminating microorganisms.

The quality of dairy products is directly related to the hygiene measures adopted during the production stages, and when they are not strictly followed, they compromise the safety of the final product and the health of the population. Considering that microbiological contamination is the most recurrent in the production chain of milk and dairy products, the monitoring of microorganisms is extremely important to avoid foodborne diseases. Thus, there is a need to encourage industries to regularly assess the quality of the water used and the dairy products generated, in addition to carrying out the correct water treatment, as well as the cleaning of water tanks and hygienic measures in all steps in food processing.

Based on the highlighted information, the importance of this work is emphasized for the surveillance of factors that may impact the food production processes and for the promotion of quality improvement in the regional production of dairy products, through the investigation of microorganisms in water and fermented milk beverage from dairy products, correlating possible health risks.

The microbiological counts of total coliforms and heterotrophic microorganisms identified above what is allowed by legislation and Aeromonas spp. in the water samples collected in this study may be evidence of poor hygienic and sanitary conditions, which may cause cross contamination with the fermented milk beverage, which did not show microbial growth of these agents, however, if exposed to these microorganisms, it may present impairment of shelf life, and even consumer health. Therefore, compliance with Good Practices is recommended, based on the continuous monitoring of the stages of product processing, from the selection of inputs and raw materials, through the evaluation of the quality of the water used, cleaning of environments, surfaces and utensils, training of food handlers, up to the distribution of the final product, in order to guarantee the quality of the food produced and prevent damage to the health of the population.

The results obtained during the experiment were compared with the norms and standards contained in the current legislation mentioned, as well as correlated with the findings in the works of other authors, being detailed in the form of reports that were delivered to the dairy participating in this study with the aim of provide an overview of the results found in the analyzed samples in order to add to the decision-making process to improve the production process. 
It is noteworthy that the study initially designed had to be reduced due to the situation of a pandemic caused by a new coronavirus (SARS-CoV-2/COVID-19) and considering: The Declaration of Emergency in World Public Health published by the World Health Organization (WHO) on January 30, 2020; Law No. 13,979, of February 6, 2020; And Ordinance No. 322, of March 17, 2020, of the Rectory of the Federal University of Recôncavo of Bahia, which suspended indefinitely the teaching activities of undergraduate and postgraduate courses in attendance at all UFRB campi.

Therefore, following the social isolation measures recommended during the pandemic related to the SARS-CoV-2 microorganism, it was not possible to carry out a broader study, previously planned, with the participation of more industries, application of a checklist and analysis, thus, future research related to the hygienic-sanitary quality of the production of dairy products in Bahia is suggested. 